\title{
Bibliography and filmography
}

\section{William Trevor}

\section{Primary texts}

A Standard of Behaviour (London: Hutchinson, 1958)

The Old Boys (London: Bodley Head, 1964)

The Boarding House (London: Bodley Head, 1965)

The Love Department (London: Bodley Head, 1966)

The Day We Got Drunk on Cake and other stories (London: Bodley Head, 1967)

Mrs Eckdorf in O'Neill's Hotel (London: Bodley Head, 1969)

Miss Gomez and the Brethren (London: Bodley Head, 1971)

The Ballroom of Romance and other stories (London: Bodley Head, 1972)

Elizabeth Alone (London: Bodley Head, 1973)

Angels at the Ritz and other stories (London: Bodley Head, 1975)

The Children of Dynmouth (London: Bodley Head, 1976)

Lovers of Their Time and other stories (London: Bodley Head, 1978)

The Distant Past and other stories (Dublin: Poolbeg Press, 1979)

Other People's Worlds (London: Bodley Head, 1980)

Beyond the Pale and other stories (London: Bodley Head, 1981)

Scenes from an Album (Dublin: Co-op Books, 1981)

Fools of Fortune (London: Bodley Head, 1983)

The Stories of William Trevor (London: King Penguin, 1983)

A Writer's Ireland: Landscape in Literature (London: Thames \& Hudson, 1984)

The News from Ireland and other stories (London: Bodley Head, 1986)

Nights at the Alexandra (London: Hutchinson, 1987)

The Silence in the Garden (London: Bodley Head, 1988)

(ed.) The Oxford Book of Irish Short Stories (Oxford: Oxford University Press, 1989)

Family Sins and other stories (London: Bodley Head, 1990)

Two Lives: Reading Turgenev and My House in Umbria (London: Viking, 1991) 
The Collected Stories (London: Viking, 1992)

Juliet's Story (London: Bodley Head, 1992)

Outside Ireland: Selected Stories (London: Penguin, 1992)

Excursions in the Real World (London: Hutchinson, 1993)

Felicia's Journey (London: Viking, 1994)

Ireland: Selected Stories (London: Penguin, 1995)

After Rain (London: Viking, 1996)

Death in Summer (London: Viking, 1998)

The Hill Bachelors (London: Viking, 2000)

The Story of Lucy Gault (London: Viking, 2002)

$A$ Bit on the Side (London: Viking, 2004)

Cheating at Canasta (London: Viking, 2007)

Love and Summer (London: Viking, 2009)

\section{Television and film screenplays}

The Old Boys (adapted by Clive Exton), BBC, 29 April 1965

The Babysitter, Series: 'Not for the Nervous', 18 August 1965

Walk's End, Series: 'Out of the Unknown', 22 December 1966

The Listener, Series: 'Mystery and Imagination', 29 March 1968

The Fifty-Seventh Saturday, Series: 'Half-Hour Story', 3 July 1968

A Night with Mrs Da Tanka, Series: 'The Wednesday Play', BBC, 11 September 1968

The Mark-Two Wife, Series: 'The Wednesday Play', BBC, 15 October 1969

The Italian Table, Series: 'The Wednesday Play', BBC, 18 February 1970

The Grass Widows, Series: 'ITV Playhouse', ITV, 24 August 1971

O Fat White Woman, Series: 'Play for Today', BBC, 4 November 1971

The General's Day, Series: 'Play for Today', BBC, 20 November 1972

Access to the Children (director: Phillip Saville), 'Series: Play for Today', BBC, 5 March 1973

Miss Fanshaw's Story, Series: 'Armchair Thirty', 11 April 1973

An Imaginative Woman, Series: 'Wessex Tales', Episode 4 (screenplay: William Trevor;

director: Gavin Millar [Thomas Hardy adaptation]), 29 November 1973

Love Affair, Series: 'ITV Playhouse', ITV, 3 July 1974

Eleanor, Series: 'Play for Today', BBC, 12 December 1974

Mrs Acland's Ghost, Series: 'Playhouse', BBC, 15 January 1975

Two Gentle People, Series: 'Shades of Greene', 30 September 1975

The Nicest Man in the World, 16 May 1976

The Love of a Good Woman, Series: 'Playhouse: The Mind Beyond', 13 October 1976

Voices from the Past, Series: 'The Crezz', 21 October 1976

Newsworthy: The Girl Who Saw a Tiger, Series: 'Scene', 1976

The Newcomers, Series: 'The Crezz', 25 November 1976

Another Weekend, Series: 'Parables', 18 August 1978

Matilda's England (aka 'Tennis Court Trilogy'), Part 1 'The Tennis Court', Part 2 'The Summer House', Part 3 'The Drawing Room' (director: Mark Cullingham), BBC in 3 parts, 18 and 25 April, 2 May 1979 
The Old Curiosity Shop (screenplay: William Trevor; director: Julian Amyes [Charles Dickens adaptation]), BBC1 1979-80 in nine parts, 9 December 1979 - 3 February 1980

The Happy Autumn Fields, Series: 'Playhouse' [Elizabeth Bowen adaptation], BBC2, 21 November 1980

Teresa's Wedding, RTÉ, 24 January 1980

Elizabeth Alone, Series: 'Playhouse', BBC2 in three parts, 3 April, 10 April, 17 April 1981

Lovers of their Time, Series: 'All for Love', 29 August 1982

The Ballroom of Romance (director: Pat O'Connor; producer: Kenith Trodd), BBC/RTÉ, 5 November 1982

Attracta (director: Kieran Hickey; producer: Douglas Kennedy), BAC Films/RTÉ/IFB, 1983

One of Ourselves (director: Pat O'Connor; producer: Kenith Trodd), BBCNI, 1983

Office Romances, 21 May 1983

Mrs Silly, Series: 'All for Love', 18 September 1983

Access to the Children (director: Tony Barry; producer: John Lynch), RTÉ/Channel 4, 3 March 1985

The Children of Dynmouth, Series: 'Screen 2', 24 April 1987

Beyond the Pale (director: Diarmuid Lawrence; producer: Robert Cooper), Series: 'Screenplay', BBC, 3 August 1989

Fools of Fortune (screenplay: Michael Hirst; director: Pat O'Connor), 1990

August Saturday, Series: 'Screenplay', BBC, 29 December 1990

Events at Drimaghleen (director/producer: Robert Cooper), Series: 'Screenplay', BBCNI, 1991

Felicia's Journey (screenplay/director: Atom Egoyam), 1999

My House in Umbria (screenplay: Richard Whitemore; director: Hugh Loncraine), 2003

\section{Selected print interviews with and short pieces by William Trevor}

'William Trevor Interviewed by Mark Ralph-Bowman', Transatlantic Review 53/54 (February 1976), 5-12

William Trevor, 'Between Holyhead and Dun Laoghaire', review of Elizabeth Bowen, Collected Stories, Times Literary Supplement (6 February 1981), 131

Clare Boylan, 'Trevor's Troubles', The Sunday Press (24 April 1983)

Melvyn Bragg, 'The most English of Irishmen', Good Housekeeping 126: 6 (December 1984), 64-5

Mira Stout 'The Art of Fiction CVIII: William Trevor', Paris Review 110 (Winter/Spring 1989/1990), www.theparisreview.org/interviews/ (accessed 11 March 2013)

Angela Neustatter, 'A Natural Curiosity', Sunday Times (26 May 1991), 6-7

Alan Jackson, 'I have Great Gaps in my Education', The Times, Saturday Review (11 April 1992), 46

Interview with Suzanne Morrow Paulson (1992), in Suzanne Morrow Paulson, William Trevor: A Study of the Short Fiction (New York: Twayne, 1993), pp. 109-20

Stephen Schiff, 'The Shadows of William Trevor', New Yorker (28 December 1992 / 4 January 1993), 158-63 
Interview with Mike Murphy, in Reading the Future: Irish Writers in Conversation with Mike Murphy, ed. Clíodhna Ní Anluain (Dublin: Lilliput Press, 2000), pp. 223-39

Constanza del Río Álvaro, 'Talking with William Trevor: "It all Comes Naturally Now"' Estudios Irlandeses 1 (March 2006), 119-24

Interview with Lisa Allardice, The Guardian, Saturday Review (5 September 2009), $12-13$

Eileen Battersby, 'I am a Fiction Writer. It is what I do', The Irish Times, Weekend Review (16 April 2011), 11

\section{Selected television and radio interviews and appearances}

Short Stories, Series: 'Cover to Cover' (interview), 3 November 1973

William Trevor, Series 'Writers in Profile', RTÉ Radio, 6 August 1976

The Book Programme (interview), 9 December 1976

Read All About It (on-screen participant), 25 March 1979

Folio: William Trevor (interview), RTÉ, 5 April 1979

Capturing the Moment, Series: 'The Book Programme' (interview), 8 June 1980

All About Books, Series: 'Russell Harty's All About Books' (interview), 19 June 1980

Kaleidoscope, interview with Mark Storey, BBC Radio 4, 16 June 1980

A City to Plunder, Series: 'Writers and Places' (written and narrated), 22 January 1981

William Trevor, Series: 'The South Bank Show', interview with Melvyn Bragg, ITV, 24 April 1983

William Trevor, Series: 'Hidden Ground' (presenter; director: Tony McAuley), BBCNI, 30 May 1990

Undercover Portraits (Profile) RTÉ/Orpheus Productions, 2 May 2002

Interview with John Tusa, BBC Radio 3, 2010 (transcript available online: www.bbc. co.uk/radio3/johntusainterview/trevor_transcript.shtml)

\section{Selected criticism on William Trevor}

Allen, Bruce, 'William Trevor and Other People's Worlds', The Sewanee Review 101:1 (1993), 138-44

Archibald, Doug, Introduction to 'William Trevor: Special issue', Colby Quarterly 38:3 (2002), 269-79

Bloom, Jonathan, The Art of Revision in the Short Stories of V.S. Pritchett and William Trevor (Basingstoke: Palgrave Macmillan, 2006)

Bonaccorso, Richard, 'William Trevor's Martyrs for Truth', Studies in Short Fiction 34:1 (Winter 1997), 113-18

— 'The Ghostly Presence: William Trevor's Moral Device', Colby Quarterly 38:3 (September 2002), 308-14

Clark, Miriam Marty, 'The Scenic Self in William Trevor's Stories', Narrative 6:2 (May 1998), 174-87

Cronin, John, 'The Two Worlds of William Trevor', in Elizabeth Maslen, ed., Comedy: Essays in Honour of Peter Dixon ed. Elizabeth Maslen (London: Queen Mary and Westfield College, 1993), pp. 274-90 
Donoghue, Denis, 'William Trevor', in Irish Essays (Cambridge: Cambridge University Press, 2011), pp. 215-25

Fitzgerald-Hoyt, Mary, William Trevor: Re-imagining Ireland (Dublin: Liffey Press, 2003)

- 'William Trevor's Cheating at Canasta: Cautionary Tales for Contemporary Ireland', New Hibernia Review 12:4 (Geimhreadh/Winter 2008), 117-33

Flower, Dean, 'The Reticence of William Trevor', The Hudson Review 43:4 (Winter 1991), 686-90

Foster, John Wilson, 'Stretching the Imagination: Some Trevor Novels', in Between Shadows: Modern Irish Writing and Culture (Dublin: Irish Academic Press, 2009), 57-71

Glitzen, Julian, 'The Truth-tellers of William Trevor', Critique 21:1 (August 1979), 59-72

Harte, Liam and Lance Pettitt, 'States of Dislocation: William Trevor's Felicia's Journey and Maurice Leitch's Gilchrist', in Ashok Bery and Patricia Murray, eds., Comparing Postcolonial Literatures (Basingstoke: Macmillan, 2000), pp. 70-81

Hill, John, "'The Past is always there in the Present": Fools of Fortune and the Heritage Film', in J. MacKillop, ed. Contemporary Irish Cinema (Syracuse: Syracuse University Press, 1999), pp. 29-39

Imhof, Rudiger, 'William Trevor', in The Modern Irish Novel: Irish Novelists after 1945 (Dublin: Wolfhound Press, 2002), pp. 139-74

Kenny, John, 'William Trevor on Screen', Film West 38 (October 1999), 18-20

Kerwin, William, 'Teaching Trevor, Teaching "The Troubles"', Eureka Studies in Teaching Short Fiction 9:2 (Spring 2009), 125-35

Larsen, Max Deen, 'Saints of the Ascendancy: William Trevor's Big House Novels', in Otto

Rauchbauer, ed., Ancestral Voices: The Big House in Irish Literature (Dublin: Lilliput Press, 1992), pp. 257-77

McAlindon, Tom, 'Tragedy, History, and Myth: William Trevor's Fools of Fortune', Irish University Review 33:2 (Autumn-Winter 2003), 291-306

McBride, Stephanie, Felicia's Journey (Cork: Cork University Press, in association with the Irish Film Institute, 2006)

— 'William Trevor's Fictional Worlds', Programme Notes Kilkenny Arts Festivall Cinemobile 'Adaptations' (8 August 2009)

MacKenna, Dolores, William Trevor: The Writer and His Work (Dublin: New Island Books, 1999)

Morrison, Kristin, William Trevor (New York: Twayne, 1993)

Mortimer, Mark, 'The Short Stories of William Trevor', Etudes Irlandaises 9 (December 1984), 161-73

—'William Trevor', Ireland Today 1031 (September 1986), 7-10

Ormsby-Lennon, Hugh, Fools of Fiction: Reading William Trevor's Stories (Dublin: Maunsel, 2005)

Patten, Eve, 'William Trevor', British Council Literature, http://literature.britishcouncil. org/

Paulson, Suzanne Morrow, William Trevor: A Study of the Short Fiction (New York: Twayne, 1993) 
Rhodes, Robert E., “"The Rest is Silence”: Secrets in Some William Trevor Stories', in James D. Brophy and Eamon Grennan, eds., New Irish Writing III: Essays in Memory of Raymond J. Porter (Boston: G.K. Hall, 1989), pp. 35-53

Russell, Richard Rankin, 'The Tragedy of Imelda's Terminal Silence in William Trevor's Fools of Fortune', Papers on Language and Literature 42:1 (2006), 73-94

Sampson, Denis, "'Bleak Splendour”: Notes for an Unwritten Biography of William Trevor', Colby Quarterly 38:3 (September 2002), 280-94

Sanger, Wolfgang, 'William Trevor and Turgenev', Irish University Review 27:1 (SpringSummer 1997), 182-98

Schirmer, Gregory A., William Trevor: A Study of His Fiction (London: Routledge, 1990)

St Peter, Christine, 'Consuming Pleasures: Felicia's Journey in fiction and film', Colby Quarterly 38:3 (September 2002), 329-39

Stinson, John J., 'Replicas, Foils and Revelation in Some Irish Short Stories of William Trevor', Canadian Journal of Irish Studies 11:2 (December 1985), 17-26

Thomas, Michael J., 'Worlds of their Own: A Host of Trevor's Obsessives', The Canadian Journal of Irish Studies 25:1-2 (July-December 1999), 441-82

- 'Usurping Spiv and Gentry: William Trevor's London', Irish University Review 31:2 (Spring-Summer 2002), 376-85

Tracy, Robert, 'Telling Tales: The Fictions of William Trevor', Colby Quarterly 38:3 (September 2002), 295-307

\section{Other literary, critical and theoretical texts cited}

Attridge, Derek, The Singularity of Literature (London: Routledge, 2004)

Bachelard, Gaston, The Poetics of Space, trans. Maria Jolas (Boston: Beacon Press, 1994)

Bardon, Jonathan, A History of Ulster (Belfast: Blackstaff Press, 2005)

Barry, Sebastian, The Secret Scripture (London: Viking, 2008)

Barry, Ursula and Clair Wills, eds, and introduction to 'The Republic of Ireland: The Politics of Sexuality 1965-1997’, in Angela Bourke et al., eds., The Field Day Anthology of Irish Writing, vol. 5 (Derry: Field Day/Cork University Press, 2002), pp. 1409-73

Barthes, Roland, Image-Music-Text, trans. Stephen Heath (London: Fontana, 1977)

- 'Striptease', in Barthes: Selected Writings, ed. Susan Sontag (Glasgow: Fontana, 1989), pp. $85-8$

Beckett, Samuel, Murphy (London: Penguin, 1967)

Benjamin, Walter, The Origin of German Tragic Drama, trans. John Osborne (London: Verso, 1998)

Bennett, Andrew and Nicholas Royle, Elizabeth Bowen and the Dissolution of the Novel (New York: St Martin's Press, 1995)

Berman, Marshall, All That Is Solid Melts into Air: The Experience of Modernity (London: Verso, 1983)

Best, Stephen and Sharon Marcus, 'Surface Reading: An Introduction', Representations 108:1 (2009), 1-21

Bhabha, Homi K., The Location of Culture (London: Routledge, 1994) 
Bowen, Elizabeth, 'The Big House', in The Mulberry Tree: The Writings of Elizabeth Bowen, ed. Hermione Lee (London: Virago, 1986), pp. 25-30

-Bowen's Court (Cork: The Collins Press, 1998)

Boym, Svetlana, The Future of Nostalgia (New York: Basic Books, 2001)

Butler Cullingford, Elizabeth, Ireland's Others: Gender and Ethnicity in Irish Literature and Popular Culture (Cork: Cork University Press, in association with Field Day, 2001)

Cairns, David and Shaun Richards, Writing Ireland: Colonialism, Nationalism, and Culture (Manchester: Manchester University Press, 1988)

Caruth, Cathy, ed., Trauma: Explorations in Memory (Baltimore: John Hopkins University Press, 1995)

-Unclaimed Experience: Trauma, Narrative and History (Baltimore: John Hopkins University Press, 1996)

Cashman, Ray, 'Critical Nostalgia and Material Culture in Northern Ireland', Journal of American Folklore 119 (2006), 137-60

Cleary, Joe, Outrageous Fortune: Capital and Culture in Modern Ireland (Dublin: Field Day, 2007)

Connolly, Thomas, Mourning into Joy: Music, Raphael, and Saint Cecilia (New Haven and London: Yale University Press, 1994)

Conrad, Kathryn C., Locked in the Family Cell: Gender, Sexuality and Political Agency in Irish National Discourse (Madison: University of Wisconsin Press, 2004)

Corkery, Daniel, The Hidden Ireland: A Study of Gaelic Munster in the Eighteenth Century (Dublin: M.H. Gill \& Son, 1924)

Crowe, Catriona, 'On the Ferns Report', The Dublin Review 22 (Spring 2006), 5-26

Davies, Norman, The Isles: A History (London: Macmillan, 1999)

Deane, Seamus, Civilians and Barbarians (Derry: Field Day Theatre Company, 1983)

- 'Heroic Styles: the Tradition of an Idea', Ireland's Field Day (London: Hutchinson, 1985), pp. 45-59

—Celtic Revivals: Essays in Modern Irish Literature 1880-1980 (London: Faber and Faber, 1985)

- A Short History of Irish Literature (London: Hutchinson, 1986)

- Strange Country: Modernity and Nationhood in Irish Writing since 1790 (Oxford: Clarendon Press, 1997)

De Man, Paul, Aesthetic Ideology (Minneapolis: University of Minnesota Press, 1996)

Derrida, Jacques, Of Grammatology, trans. Gayatri Chakravorty Spivak (Baltimore: John Hopkins University Press, 1974)

— 'Living On/Border Lines', in Harold Bloom, ed., Deconstruction and Criticism (London: Routledge and Kegan Paul, 1979), pp. 75-176

Dillon, Brian, Ruins (London and Cambridge, MA: Whitechapel Gallery and The MIT Press, 2011)

Eagleton, Terry, 'The Subject of Literature', Cultural Critique 2 (Winter 1986), 95-104

- Heathcliff and the Great Hunger (London: Verso, 1995)

Ellis Owen, Arwel, The Anglo-Irish Agreement: The First Three Years (Cardiff: University of Wales Press, 1994)

Faulkner, William, Go Down, Moses (New York: Vintage Books, 1990) 
Felski, Rita, 'Suspicious Minds', Poetics Today 32:2 (2011), 215-34

-Introduction to New Literary History 42:2 (2011), v-ix

Foster, R.F., Modern Ireland 1600-1972 (London: Allen Lane, 1988)

Frawley, Oona, Irish Pastoral: Nostalgia and Twentieth-Century Irish Literature (Dublin: Irish Academic Press, 2005)

Friel, Brian, Translations (London: Faber and Faber, 1981)

Garland Mann, Susan, The Short Story Cycle: A Genre Companion and Reference Guide (Westport, CT: Greenwood, 1989)

Garratt, Robert F., Trauma and History in the Irish Novel: The Return of the Dead (Basingstoke: Palgrave Macmillan, 2011)

Gibbons, Luke, 'Challenging the Canon: Revisionism and Cultural Criticism', in Seamus Deane et al., eds., The Field Day Anthology of Irish Writing, vol. 3 (Derry: Field Day, 1991), pp. 561-8

Harrington, John P., ed., Modern Irish Drama (New York: W.W. Norton, 1991)

Hart, Peter, The IRA at War: 1916-1923 (Oxford: Oxford University Press, 2003)

Heaney, Seamus, North (London: Faber and Faber, 1975)

-Opened Ground: Poems 1966-1996 (London: Faber and Faber, 1998)

Huffer, Lynne, Maternal Pasts, Feminist Futures: Nostalgia, Ethics, and the Question of Difference (Stanford: Stanford University Press, 1998)

Joyce, James, Dubliners, ed. Terence Brown (London: Penguin, 2000)

-Ulysses: Annotated Students' Edition, ed. Declan Kiberd (London: Penguin, 1992)

— Selected Letters of James Joyce, ed. Richard Ellmann (London: Faber and Faber, 1975)

Keegan, Claire, Antarctica (London: Faber and Faber, 1999)

Kiberd, Declan, Inventing Ireland: The Literature of the Modern Nation (London: Jonathan Cape, 1995)

Klein, Bernhard, On the Uses of History in Recent Irish Writing (Manchester: Manchester University Press, 2007)

Kołakowski, Leszek, Why is There Something Rather than Nothing? (London: Penguin, 2008)

Kreilkamp, Vera, The Anglo-Irish Novel and the Big House (Syracuse: Syracuse University Press, 1998)

Love, Heather, 'Close But Not Deep: Literary Ethics and the Descriptive Turn', New Literary History 41:2 (2010), 371-91

Low, Gail, 'Streets, Rooms, and Residents: The Urban Uncanny and the Poetics of Space in Harold Pinter, Sam Selvon, Colin MacInnes and George Lamming,' in Glenn Hooper, ed., Landscape and Empire (Aldershot: Ashgate, 2005), pp. 159-76

Lowenthal, David, The Past is a Foreign Country (Cambridge: Cambridge University Press, 1985)

McGahern, John, Nightlines (London: Faber and Faber, 1970)

McIntyre, Alasdair, After Virtue: A Study in Moral Theory, 2nd edn (London: Duckworth, 1981)

MacPhail, Fiona, 'Major and Majestic: J.G. Farrell's Troubles', in Jacqueline Genet, ed., The Big House in Ireland: Reality and Representation (Dingle: Brandon, 1991), pp. 243-52 
Meaney, Gerardine, Sex and Nation: Women in Irish Culture and Politics, LIP Pamphlet (Dublin: Attic Press, 1991)

- 'The Sons of Cúchulainn: Violence, the Family, and the Irish Canon', Eire-Ireland 41:1-2 (2006), 242-61

Moane, Geraldine, Gender and Colonialism: A Psychological Analysis of Oppression and Liberation (London: Macmillan, 1999)

Montague, John, The Rough Field (Dublin: Dolmen Press, 1979)

Murphy, Gerard, The Year of Disappearances: Political Killings in Cork, 1921-1922 (Dublin: Gill and Macmillan, 2010)

Murphy, Maureen, 'The Irish Servant Girl in Literature', in America and Ulster: A Cultural Correspondence, 'Writing Ulster Series' 5 (Ulster: Ulster University Press, 1998), pp. 133-48

Ní Dhomhnaill, Nuala, Selected Essays, ed. Oona Frawley (Dublin: New Island Books, 2005)

O’Brien, Flann, 'The Dancehalls', The Bell 1:5 (February 1941), 44-52

-At Swim-Two-Birds (London: Penguin, 1967)

O'Faoláin, Nuala, 'This Thick Excitement', Salon (21 June 2004)

Parker, Michael, Northern Irish Literature 1975-2006 (Basingstoke: Palgrave, 2007)

Peach, Linden, The Contemporary Irish Novel: Critical Readings (Basingstoke: Palgrave, 2004)

Phillips, Caryl, 'Kingdom of the Blind', The Guardian (17 July 2004)

Potts, Donna, 'The Irish Novel After Joyce', in Brian W. Shaffer, ed., A Companion to the British and Irish Novel 1945- 2000 (Oxford: Blackwell, 2005), pp. 457-68

Power, Vincent, Send 'Em Home Sweatin': The Showband Story (Cork: Mercier Press, 2000)

Primorac, Antonja, review of conference proceedings, Adaptation 5:10 (2012), 129-35

Proctor, James, Dwelling Places (Manchester: Manchester University Press, 2003)

Rayfield, Donald, Anton Chekhov: A Life (Evanston, IL: Northwestern University Press, 1997)

Sedgwick, Eve Kosofsky, Touching Feeling: Affect, Pedagogy, Performativity (Durham: Duke University Press, 2003)

Shakespeare, William, The Norton Shakespeare, eds. Stephen Greenblatt, Walter Cohen, Jean E. Howard, Katharine Eisaman Maus (New York: W.W. Norton, 1997)

Shubik, Irene, Play for Today: The Evolution of Television Drama (Manchester: Manchester University Press, 2000)

Sinfield, Alan, Literature Politics and Culture in Postwar Britain (Oxford: Blackwell, 1989)

Smyth, Ailbhe, ed., The Abortion Papers, Ireland (Dublin: Attic Press, 1992)

Spenser, Edmund, A View of the Present State of Ireland, eds. Andrew Hadfield and Willy Maley (Oxford: Blackwell, 1997)

Stewart, Susan, On Longing: Narratives of the Miniature, the Gigantic, the Souvenir, the Collection (Durham: Duke University Press, 2007)

Strawson, Galen, 'Against Narrativity', Ratio 17 (2004), 428-52

$\mathrm{Su}$, John, Ethics and Nostalgia in the Contemporary Novel (Cambridge: Cambridge University Press, 2005) 
Tóibín, Colm, Introduction to The Penguin Book of Irish Fiction (London: Penguin, 1999), pp. ix-xxxiv

Valente, Joseph, The Myth of Manliness in Irish National Culture, 1880-1922 (Urbana: University of Illinois Press, 2011)

Weil, Simone, Gravity and Grace (London: Routledge, 2002)

Wills, Clair, 'Women Writers and the Death of Rural Ireland: Realism and Nostalgia in the 1940s', Eire-Ireland 41:1-2 (2006), 192-212

-That Neutral Island: A Cultural History of Ireland During the Second World War (London: Faber and Faber, 2007)

Wilson, Colin, The Outsider (London: Victor Gollanz, 1956)

Wordsworth, William, William Wordsworth, ed. Stephen Gill (Oxford: Oxford University Press, 1984)

Yeats, W.B., Yeats's Poems, ed. A. Norman Jeffares (Basingstoke: Macmillan, 1989)

Zagarell, Sandra A., 'Narrative of Community: The Identification of a Genre', Signs 13:3 (1988), 498-527 